\title{
Innovative Competency Analysis of the Turkish Technical Textile Sector Based on AHP and FCE Methods
}

\author{
Pelin Ofluoğlu Küçük, Turan Atılgan \\ Ege University, Engineering Faculty, Department of Textile Engineering, 35040, Bornova, İzmir
}

Corresponding Author: Pelin Ofluoğlu Küçük, pelinofluoglu@gmail.com

\begin{abstract}
Today, it is known that successful companies in innovation applications have been maintaining their competitive power and even superiority in competition. In addition to successful innovation applications into practice, it is also necessary to analyze the innovation capabilities of enterprises on a regular basis. According to the findings based on these regular analyses and evaluations, the strengths and weaknesses of firms in innovation creation processes can be determined. In this respect, the data obtained through the field study, conducted with the technical textiles companies among the top 500 industrial enterprises in Turkey, is evaluated within the methods of AHP and FCE (Fuzzy Comprehensive Evaluation). According to the research result, the innovation capability of the Turkish technical textile sector is measured as "Fair level" and the factors that bring the innovation capability of the sector to this final result are explained one by one.
\end{abstract}

\author{
ARTICLE HISTORY \\ Received: 08.12.2017 \\ Accepted: 01.09.2018
}

\section{KEYWORDS}

Textile sector, technical textiles, innovation, Fuzzy Comprehensive Evaluation, Analytic Hierarchy Process

\section{INTRODUCTION}

In order for innovative applications to achieve success, it is necessary to regularly analyze the innovation capabilities of enterprises, as well as improving the working conditions, in the direction of "Unmeasurable things cannot be managed and developed". By doing that, the weak and strong aspects of the enterprises' innovation creation processes can be identified and the continuity of the successful innovation processes can be ensured. The measurement of innovation power has been applied in the literature through different analysis techniques and in various sectors such as food and agriculture. However, the number of studies based on defining the components of innovation process evaluation in the textile sector, analysis of these factors, and analysis of innovation process management within the firm and sectoral-levels has remained limited in the literature. So far, no systematic research has been done on the innovation capability analysis of the technical textile sector. Therefore, it is thought that this study will contribute to the academic world by presenting the effects of innovation applications on firm success indicators in the technical textile sector, through concrete statistical data.

The Turkish technical textile sector has various advantages, such as being a sub-branch of an advanced textile industry which makes great contributions to total exports of the country, qualified human resource opportunities, wellestablished textile education institutions, a broad domestic market, advanced transportation network, well and modernly equipped laboratory infrastructure and also trade agreements with various countries. Looking at the commercial data of the Turkish technical textiles sector, it is observed that the volume of foreign trade in this area has increased significantly over the last five years. Imports of technical textiles increased to 1.4 billion dollars as of 2017 , whereas, Turkey is technical textile exports reached 1.5 billion dollars in 2017. Therefore, Turkey's exports in this field has passed the imports during the latest years $[1,2]$.

Moreover, Turkish textile industry has acted as a supplier for many years in line with the customer demands. Thanks to the changing perspective of the developing technological infrastructure, well-educated workforce and the developing 
perspective of the sector managers, it is observed that the textile sector has become abler to direct customers and create new products and processes with its own possibilities and brain team. For these reasons, innovation culture has started to be more apparent in the textile industry in recent years and this situation has started to bring the results. The technical textile sector also benefits from the developing innovation culture in Turkey, like the textile sector as a whole in which it is one of the sub-branches. In the following periods, it can be said that the culture of innovation, that will become widespread in the sector, will be supportive of a wider range of innovative practices.

Due to this importance of the sector, the analysis of innovation capability of the firms operating in the Turkish technical textiles sector was carried out through the combination of the Analytical Hierarchy Process (AHP) and Fuzzy Comprehensive Evaluation Method (FCE). Based on the sample of the study, the advantages and disadvantages of the Turkish technical textiles sector in international competition were tried to be reflected and various suggestions were made in order to increase the innovation capability of the sector.

\section{LITERATURE REVIEW}

The European Commission regularly provides a comparative analysis of innovation performance in EU countries, other European countries, and regional neighbors. "Innovation Scoreboard" assesses relative strengths and weaknesses of national innovation systems. The measurement framework distinguishes between 27 different indicators in total. Countries fall into four performance groups, which are innovation leaders, strong innovators, moderate innovators and modest innovators. According to the innovation index obtained in 2018, countries such as Denmark, Finland, Luxembourg, the Netherlands, and Sweden are Innovation Leaders. Countries such as Bulgaria and Romania are in the class of Modest Innovators. In the context of this classification, Turkey is among the moderate innovative countries $[3,4]$.

Looking at patent and utility model applications, it is observed that 84 applications were made in the textile industry in 2016 and 86 applications were made in the clothing industry [5]. One of the reasons of this situation is that, while patent and utility model applications in the textile sector are generally based on the product and process innovation, the focus of the innovation applications in the clothing sector is mainly on design and branding activities. In addition, while in the past years, more patent and utility model applications were made in the textile products sector compared to clothing, the efforts and studies in the clothing industry have been fruitful in recent years and this situation has been reflected in the data in terms of the increase in these applications.

Innovation is a complex, nonlinear and a multidimensional process that is difficult to predict. For this reason, there is no single criterion and method that can identify and measure the properties of this holism. Examining both Turkish and international literature, the number of studies carried out in the field of innovation ability analysis of enterprises, especially at the national level, was found to be limited. On the other hand, studies related to innovation ability analysis in the technical textiles sector have been determined to be scarce.

The official standardization of innovation surveys was enabled after the preparation of the Oslo Manual by OECD and Eurostat. The latest version of the guide was translated into Turkish by TÜBITAK [6]. In the literature, various innovation performance analysis studies were performed in the textile sector. In these studies, textile firms were evaluated within one sector or in combination with different sectors in terms of their innovation capability. In general, various criteria have been determined and field research has been carried out in order to obtain the data based on these criteria. In the evaluation of the obtained data, different methods have been applied. Balance scorecard method [7]; data envelopment technique [8]; factor and regression analysis [9]; multistage Delphi method and fuzzy logic method [10]; entropy weight rating, grey relational analysis [11]; parametric and non-parametric tests in accordance with social network analysis (SNA) [12] are some of examples of the utilized methods in the literature.

\section{MATERIAL AND METHOD}

A field research was carried out with the textile companies operating in the field of technical textiles, which are among the large-scale industrial enterprises of Turkey.

The data were obtained through face-to-face interview technique conducted with the companies using a questionnaire, which was arranged in accordance with the objectives. In addition, published statistics, research reports, theses, articles and papers constituted secondary data sources of the study. Considering the scope of the study, it was necessary to include the technical textiles companies, which are among the large-scale companies in Turkey that could allocate more budget to the innovation activities. For these reasons, the largest 1000 company list prepared by Istanbul Chamber of Industry (ISO), the list of companies operating in the technical textiles field prepared by ITKIB, the list of textile firms with $\mathrm{R} \& \mathrm{D}$ centers announced by Turkish Ministry of Industry, and other companies that were found suitable for the study by the experts working in the field of technical textiles were utilized in order to generate the sample of this study. Within the framework of the mentioned sample forming criteria, twenty technical textile companies were selected as the most suitable companies for data collection. In consequence of the negotiations, fifteen of these technical textile companies agreed to share data. These companies are located in the provinces of Kahramanmaras, Gaziantep, Bursa, Izmir and Tekirdağ in Turkey, and they operate technical textiles activities in various branches 
accepted all over the world, such as geotextiles, automotive textiles etc. [13].

Considering the scope of the study, a hierarchy of criteria was formed in order to analyze the innovation related activities exhibited by the companies operating in the field of technical textiles and to prepare the ground for the methods to be used in the analysis of the data. These criteria are shown in the Table-1 below.

Within the frame of the analysis, five main criteria were determined, namely, innovation investment force, technology and human resources, communication opportunities, innovation environment and innovation production and management. These main criteria are also divided into subcriteria. The criterion of innovation investment force implies the size of the investment allocated to $R \& D$ activities in order to create innovative applications within the company. This criterion is divided into two groups: The ratio of the amount of budget allocated to R\&D activities $(\%)=($ Budget of the $R \& D$ activities/Total budget) and the ratio of the budget allocated to the training required for $R \& D$ personnel $(\%)=$ (Budget allocated to the education/ Total R\&D budget). Technology and human resources criterion is divided into two subcriteria: The technology level of equipments used for R\&D activities (Via verbal judgement set) and the ratio of $R \& D$ personnel to all personnel in the company (\%). The criterion of communication opportunities is for determining the level of innovation-oriented communication across the company and it is divided into four sub-criteria: The level of innovation-oriented communication between the company departments, the level of innovation-oriented communication with suppliers, the level of innovation-oriented communication with customers, and the level of innovation-oriented communication with other institutions (public, university, industry, etc.). These criteria were evaluated through a verbal judgement set. Innovation environment means the evaluation of the environment in which the company is located, from the perspective of innovation. This criterion is divided into three sub-criteria: The Company's competitiveness in the entire Turkish technical textiles market, the state support for innovation provided to technical textile enterprises and the innovation-oriented cooperation level of the company with other institutions. These criteria were also evaluated through the verbal judgement set. Innovation production and management, which is the last main criterion, aims to determine the level of effective management of innovative activities and the transformation of these activities into commercial benefits within the company. This criterion comprises the following sub-criteria: The number of patents (numerical data), the number of utility models (numerical data), the number of industrial designs (numerical data), the number of the completed projects (numerical data), the number of scientific publications (numerical data), average new product development time (numerical data), the level of internal innovation incentive system (verbal judgement set) and commercial turnover ratio of the R\&D activities (\%) [13].

Table 1. The criteria used to analyze the innovation capability

\section{Main criteria Sub-Criteria}
1. Innovation
investment force $\quad 2$. The ratio of the budget allocated to the training required for R\&D personnel $(\%)=($ Budget allocated to the education/ Total R\&D budget)

\section{Technology and $\quad$ 1. The technology level of equipments used for R\&D activities (Verbal judgement set) \\ human resources $\quad 2$. The ratio of $\mathrm{R} \& \mathrm{D}$ personnel to all personnel in the company (\%)}
3. Communication opportunities
2. The level of innovation-oriented communication with suppliers (Verbal judgement set),
3. The level of innovation-oriented communication with customers (Verbal judgement set),
4. The level of innovation-oriented communication with other institutions (public, university, industry, etc.) (Verbal judgement set)

1. The level of innovation-oriented communication between the company departments (Verbal judgement set),

1. The company's competitiveness in the entire Turkish technical textiles market (Verbal judgement set),
4. Innovation
2. The state support for innovation provided to technical textile enterprises (Verbal judgement set),
environment
3. The innovation-oriented cooperation level of the company with other institutions (Verbal judgement set)

1. The number of patents (Numerical data),
5. Innovation
2. The number of utility models (Numerical data),
production and
3. The number of industrial designs (Numerical data),
management
4. The number of the completed projects (Numerical data),
5. The number of scientific publications (Numerical data), 
6. Average new product development time (Numerical data),
7. The level of internal innovation incentive system (Verbal judgement set),
8. Commercial turnover ratio of the R\&D activities (\%)

The combination of AHP, point allocation and FCE methods were utilized in realization of the innovation analysis of the Turkish technical textile sector, due to their advantages provided and their suitability for the study goal. By considering the above criteria, innovation ability analysis requires a combination of both qualitative and quantitative data, and selected methods are capable of adapting to this purpose. AHP and point allocation methods were used to determine the weights of all criteria. For this purpose, the criteria were asked to be compared in pairs by using the scale in the range of 1-9, which was developed by Satty [14] for the AHP method. The consistency of the matrices used within the method was tested by means of $\mathrm{CR}$ values. Moreover, within the scope of the study, evaluations were carried out depending on the multiple experts' opinion to avoid the bias that may be present. To perform the aggregation of these multiple ideas, arithmetic method is utilized. Although it is possible to combine these data with different methods, it has been observed that one of the frequently preferred methods in the literature is the arithmetic mean method $[15,16]$. Another method of determining the relative weights of the criteria is the method of point allocation. In addition to the AHP method, this method is also included in the study because of the reason that innovation production and management criteria comprises eight sub-headings in total. Since the increase in the number of criteria will also result in the increase of the pair-wise comparisons, the responder is more likely to show distraction and reluctance, resulting from the extension of the questionnaire, could negatively affect the reliability of the questionnaire. In the most basic form, the method aims to determine the relative weights based on the distribution of a score between the criteria, conducted by the responder [17].

Other method used was the fuzzy comprehensive evaluation (FCE). This method is developed mainly for the multistage, multi-variable and wide-area related problems [18, 19, 20, 21]. The basis of this method includes: a set of evaluation standards $(U)$, evaluation set $(V)$, the fuzzy membership degree of appraisal of the factors $(r)$, singlefactor fuzzy evaluation matrix $(R)$, the weight set of the factors $(A)$, the fuzzy comprehensive membership grade set (B) obtained by the combination of $A$ and $R$. The evaluation set $V$, includes the entire possible judgment degrees, and is determined by the expert opinions in line with the criteria and the area studied, based on linguistic variables [22]. Similar with the evaluation set, various formulations and approaches exist in the literature for membership degrees of the factors that compose the matrix of $R$. It is observed that membership degrees of the factors (criteria) are shaped by experts according to the scope of study [18, 23, 24, 25]. In the frame of the method, decision-making matrices have been formed for the purpose of mathematical reflection of expert opinions. Based on the matrices obtained, fuzzy comprehensive evaluations were performed. In this way, both the "must haves" for a successful innovation management process and the current situation of the technical textile companies in innovation were determined and analyzed.

\section{GENERAL FINDINGS OF THE RESEARCH}

This part of the study was taken into consideration within the steps followed in the integrated use of AHP and FCE methods.

1. Determination of the evaluation factor set: Firstly, the factor set to be evaluated within the framework of the FCE method was determined. In other words, the hierarchical structure of the problem was determined to be used in the AHP method. In total, twenty-four factors, consisting of five main and nineteen sub-factors, are listed as follows: $\mathrm{U}=\{\mathrm{U} 1, \mathrm{U} 2, \ldots, \mathrm{U} 24\}=\{$ Innovation investment force, Technology and human resources, ...., The commercial turnover ratio of the $\mathrm{R} \& \mathrm{D}$ activities $\}$

2. Determination of the factor weights: The factor weights were obtained via pair-wise comparisons of AHP procedure and the average weights were calculated based on the decision makers' appraisals, through the program of Expert choice 11. For the determination of the weights of innovation production and management criteria, SPSS-20 program was used for the point allocation method. The following table summarizes the criteria weights obtained in line with the opinions of the managers of fifteen companies included in the study (Table 2). The table is compiled according to the ranking of the main and sub criteria weights.

The innovation ability of technical textile companies is primarily driven by innovation production and management (27.7\%), secondly by innovation environment (21.7\%), third by technology and human resource $(19.4 \%)$, fourth by innovation investment force $(18.6 \%)$ and finally by the effectiveness of communication opportunities (12.7\%). Therefore, in terms of companies, the tangible products obtained because of innovative activities, the conversion of these products into commercial benefits and the effective management of these factors constitute the most important criteria in constituting the innovation capability. All of the decision matrices obtained through pair-wise comparisons provide the rule of $\mathrm{CR}<0.10$ for reliability. Therefore, it is possible to say that the data can be regarded as valid and reliable. 
3. Determination of the evaluation set and standard membership degree of the evaluation set

Two types of evaluation sets were determined to obtain the judgments based on the verbal and quantitative data. This need arises from the fact that the criteria such as "the level of innovation-oriented communication with the suppliers of the company" criterion is subjected to verbal evaluation, while the criteria such as "number of the patents" need to be analyzed within numerical data. The evaluation set used to determine the entire possible verbal judgments is as follows: $\mathrm{V}=\left\{\mathrm{v}_{1}, \mathrm{v}_{2}, \mathrm{v}_{3}, \mathrm{v}_{4}\right\}$ \{Excellent, good, fair, poor $\}$. These evaluation set degrees were assigned by the company managers. The membership degree set of the evaluation expressions above is as follows: $\mathrm{u}=\{1 /$ excellent, $0.8 / \mathrm{good}$, $0.6 /$ fair, $0.1 /$ poor $\}$
Membership classifications for numerical data are determined in the light of the numerical data obtained from companies. The maximum and minimum values used in the creation of these membership classes and the number of these classes can be assigned and created by experts according to the former studies [26, 27, 28]. Accordingly, four equal-sized membership classes are categorized by taking the lower and upper values of the obtained data into account. For example, the upper value of data for the innovation investment force criterion is 15 and the lower value is 0.5 . For this reason, the class size, which will include both limits and provide data distribution to four classes, is calculated as 3,5. Other classes were also formed according to this view. The table below shows the membership classifications of the main and the sub-criteria based on numerical data (Table 3).

Table 2. Innovation ability factor weights obtained through AHP

\begin{tabular}{|c|c|}
\hline Factor sets & Weight sets of the factors \\
\hline $\begin{array}{l}\text { A (Main criteria): Innovation production and management, innovation environment, technology and } \\
\text { human resources, innovation investment force, communication opportunities }\end{array}$ & $\begin{array}{l}A=(0.277, \quad 0.217, \quad 0.194 \\
0.186,0.127)\end{array}$ \\
\hline $\begin{array}{l}\mathbf{A}_{1} \text { (Innovation production and management): Commercial turnover ratio of the R\&D activities, } \\
\text { average new product development time, number of the completed projects, number of the patents, } \\
\text { number of the industrial designs, the level of internal innovation incentive system, number of the } \\
\text { utility models and the number of scientific publications }\end{array}$ & 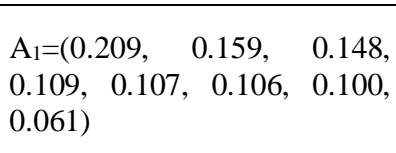 \\
\hline
\end{tabular}

A 2 (Innovation environment): The company's competitiveness in the entire Turkish technical textiles market, the innovation-oriented cooperation level of the company with other institutions and $\mathrm{A}_{2}=(0.650,0.195,0.155)$ the governmental incentives for innovation provided to technical textile enterprises

A3 (Technology and human resources): The technology level of equipments used for R\&D activities and the ratio of $R \& D$ personnel to all personnel in the company

$\mathrm{A}_{3}=(0.617,0.383)$

A $_{4}$ (Innovation investment force): The ratio of the budget allocated to the training required for R\&D personnel and the ratio of the amount of budget allocated to R\&D activities and

A5 (Communication opportunities): The level of innovation-oriented communication with customers, the level of innovation-oriented communication between the company departments, the level of innovation-oriented communication with suppliers and the level of innovation-oriented communication with other institutions

$\mathrm{A}_{5}=(0.334, \quad 0.267, \quad 0.216$ $0.182)$

Table 3. Membership degree set of criteria based on numerical evaluation

\begin{tabular}{|c|c|c|c|c|c|}
\hline \multirow[t]{2}{*}{ Main Criteria } & \multirow[t]{2}{*}{ Sub-criteria } & \multicolumn{4}{|c|}{ Membership degree set of numerical data } \\
\hline & & Excellent & Good & Fair & Poor \\
\hline \multirow[t]{2}{*}{$\begin{array}{l}\text { Innovation } \\
\text { investment force }\end{array}$} & $\begin{array}{l}\text { Budget of the R\&D activities/Total budget } \\
(\%)\end{array}$ & 10,8 and above & $7.2-10.7$ & $3.6-7.1$ & $0-3.5$ \\
\hline & $\begin{array}{l}\text { Budget allocated to the } \\
\text { Education/Total R\&D budget (\%) }\end{array}$ & 36.3 and above & $24.2-36.2$ & $12.1-24.1$ & $0-12$ \\
\hline $\begin{array}{l}\text { Technology and } \\
\text { human resources }\end{array}$ & $\begin{array}{l}\text { The ratio of R\&D personnel to all personnel } \\
\text { in the company }(\%)\end{array}$ & 4.8 and above & $3.2-4.7$ & $1.6-3.1$ & $0-1.5$ \\
\hline \multirow{5}{*}{$\begin{array}{l}\text { Innovation } \\
\text { production } \\
\text { and management }\end{array}$} & Number of the patents & 30 and above & $20-29$ & $10-19$ & $0-9$ \\
\hline & Number of the utility models & 6 and above & $4-5$ & $2-3$ & $0-1$ \\
\hline & Number of the industrial designs & 9 and above & $6-8$ & $3-5$ & $0-2$ \\
\hline & Number of the completed projects & 168 and above & $112-167$ & $56-111$ & $0-55$ \\
\hline & Number of scientific publications & 30 and above & $20-29$ & $10-19$ & $0-9$ \\
\hline
\end{tabular}


4. Establishing the single-factor fuzzy evaluation matrices (R): The evaluations of verbal expression-based factors were converted into fuzzy sets of the above-mentioned set of verbal judgments. In other words, the appraisal set of $\mathrm{R}$ can be considered as the fuzzy subset of $\mathrm{V}$. In the creation of matrices, the membership degrees of the factors were utilized and they were formed by considering the secondary criteria related to their main criteria. Fuzzy R matrices formed in the light of the data obtained within the scope of the study considering the membership degrees of subfactors, are shown below.

The matrix of R1 is shown below as an example, containing the normalized data for the innovation investment force criterion. This criterion comprises the ratio of the amount of budget allocated to $R \& D$ activities (R\&D activities budget/total budget) and the ratio of budget allocated to the training required for $R \& D$ personnel (budget allocated to education/total $R \& D$ budget) based on the numerical data, as stated previously. Numerical data for the sub-criteria mentioned and membership classes (Table 2) based on the numerical data were utilized in forming this evaluation matrix. Similarly, the matrix (R2), which is created for the technology and human resource criterion, is shown below. This criterion covers level of equipments used for R\&D activities (verbal judgement set) and the ratio of $R \& D$ personnel to all personnel in the company (\%). Data resulting from the verbal evaluations, membership degree set of the evaluation expressions (Excellent, good, fair, good), numerical data and membership degree set of numerical data (Table 2) related to these criteria were utilized to form this matrix.

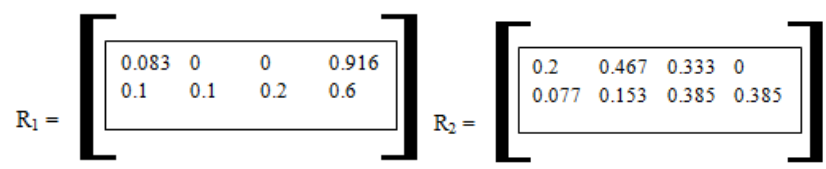

5. Determining the fuzzy comprehensive membership grade sets of the factors and the overall comprehensive membership grade of the hierarchy

At the primary level, the weights (A) and evaluation matrices (R) of all sub-criteria were multiplied for each main criteria and fuzzy membership sets were determined. Afterwards, at the secondary level, the most comprehensive fuzzy membership set of the hierarchy (B) was obtained via the weights of the main criteria and fuzzy comprehensive membership sets. For example, the fuzzy comprehensive membership set of the innovation investment force criterion $\left(B_{1}\right)$ is shown as follows.

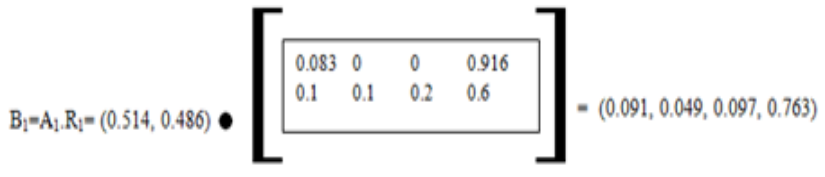

At the secondary level, the relative factor weights of the main criteria and the fuzzy comprehensive membership sets of each criteria were benefited in obtaining the most comprehensive fuzzy membership set of B.

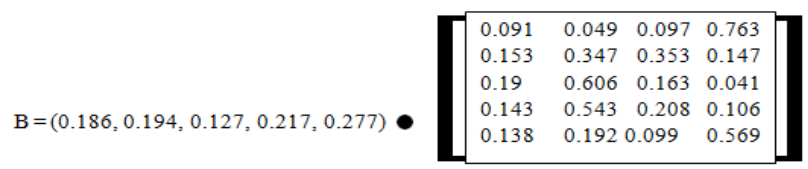

$\mathrm{B}=(0.140,0.324,0.180,0.356)$

The next step is determining the numerical value of the innovation power of the Turkish technical textiles sector and defining the class in which this data corresponds to the judgment set. In order to make this assessment, the most comprehensive fuzzy membership grade of the data set was obtained with the help of the following formula. The formula used for this purpose is as follows: $F=B \cdot u^{T}, u^{T}$ : $(1,0.8,0.6,0.1)$. Here, "u" represents the membership degree set of the evaluation expressions.

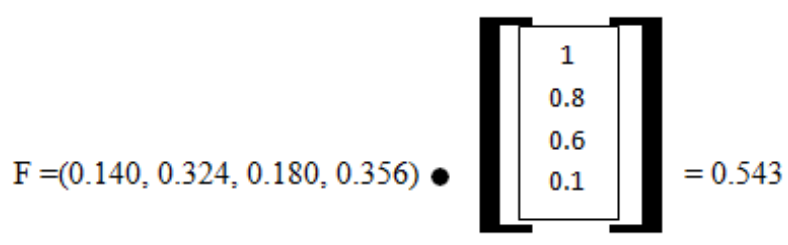

6. Reaching the final judgment: The obtained value of " 0.543 " becomes included in the evaluation expression set of "Fair", which is the final and integrated evaluation result, by taking the distance between the evaluation result and the membership degree set of the evaluation expression into account. Therefore, in the light of the evaluations, it can be assumed that the innovation ability of the Turkish technical textiles sector performs at the fair level.

\section{DISCUSSION, GENERAL EVALUATION AND CONCLUSIONS}

The level of the integrated innovation ability of the Turkish technical textiles sector revealed in this study has been similar to the position of Turkey in innovation within the European countries, which was stated as the moderate class. 
According to the opinions of the R\&D managers, the area that needs to be given the most priority among the criteria that affect the innovation capabilities of technical textile companies is the innovation production and management in terms of the main criteria. Similarly, the commercial turnover ratio of the $\mathrm{R} \& \mathrm{D}$ activities becomes the most important and effective sub-criteria. This ratio ranges between $5 \%$ and $100 \%$ according to the data obtained from the companies and the average commercial turnover ratio of the $\mathrm{R} \& \mathrm{D}$ activities in technical textiles is $57.3 \%$. Looking at the literature, this figure is defined as $55 \%$ on average in the fields of technology, industrial products and consumer goods in which the technical textiles sector takes place [29]. The data of this study becomes consistent with these results in the literature. One of the reasons why this ratio is stated higher than the average is that in some companies new product development processes are purely directed according to the customer requests. On the other hand, the limited commercial turnover ratio mainly stems from the following reasons. One of these reasons is the effort in realization of a large number of projects, however, not achieving success in the entire number. The other reason is that $\mathrm{R} \& \mathrm{D}$ activities in the technical textiles field are more backward compared to the conventional textiles products with a wider sales volume.

Average new product development time becomes of secondary importance. According to the data obtained within the scope of the study, this period ranges between 2 months and 15 months and the average duration of a new product development in technical textiles companies is 5.4 months. This criterion is followed by the number of completed projects. According to the survey carried out, this number ranges between 0 and 219 and technical textile companies have 62 completed projects on average. These projects include the partnerships conducted with the external stakeholders such as TUBITAK or universities, as well as the ones realized by internal resources, which last at least 6 months and implemented for innovations to be realized in company products, processes and services. It was observed that $75.3 \%$ of the innovative projects realized in technical textile enterprises were based on new product innovation, $16 \%$ on process innovation, $5.5 \%$ on organizational innovation and $3.2 \%$ on marketing innovation.

The patent, industrial design and utility model ownerships of Turkish technical textiles companies have lower significance levels in terms of enabling both commercial earnings and the innovation ability. It is observed that the number of patents varies between 0 and 37, and companies have 6 patents on average. It is observed that the number of industrial designs varies between 0 and 8 , on average companies have only 1 certified industrial design. Looking at the number of utility models, it is observed that companies have an average of 1 utility model and this number varies between 0 and 5 within the technical textiles companies. In addition, it is stated that the products produced in Turkish technical textiles sector are mainly shaped in line with the feedback and requests of customers and therefore the companies in the sector prefer to carry out their activities towards customer demands rather than trying to meet the requirements of such certifications. According to the study, the ratio of the budgets allocated for innovation activities are above the general average in the companies with the highest number of patent ownerships. Correspondingly, their average product development times are below the general average, and the ratio of the new product developments turning into commercial benefits is above the average. Moreover, it is observed that technical textile companies have less demand for utility model applications because of the reason stated by them is that the protection period of utility models is less than patents and this kind of protection does not require a step of invention.

The presence of a system that encourages innovative activities is of less significance in terms of creating the innovation power of companies compared to other criteria and the systems that encourage innovative activities are carried out at a "good" level throughout the enterprises according to interviewed managers. However, the number of scientific publications has become the criterion that is considered to be least important in influencing innovation power. The reasons of this situation are that scientific publications play an important role in strengthening the prestige of companies, but cannot be turned into an advantage that is a priority for customers or provide commercial earnings. It is observed that the number of the scientific publications varies between 0 to 35 , and on average, the companies have eight scientific publications.

The second most important main factor that constitutes the innovation power of enterprises is the environment of innovation in which the company is located. Technical textile enterprises participating in the study rate the competitiveness skills, the innovation-oriented cooperation level of the company with other institutions and the governmental incentives for innovation provided to technical textile enterprises as "good", within the evaluation set for classification. It has been determined that the technology level of the equipment utilized for $R \& D$ purposes is "good", throughout the large-scale technical textile enterprises participating in the study. The majority of the companies agree that the number of $R \& D$ personnel employed or the ratio of these personnel in total personnel is not an adequate data in formation of innovative activities solely. It was determined that this ratio changes between $0,4 \%$ and $6,1 \%$ in the technical textile companies participating in the study and the average ratio of $R \& D$ personnel is $2,33 \%$.

One of the other criterion that enables companies to come to the forefront compared to their competitors in their innovation ability is their investment force. In the scope of the study, innovation investment of the companies was examined within two categories: The ratio of the amount of budget allocated to R\&D activities $(\%)=($ Budget of the 
R\&D activities/Total budget) and the ratio of the budget allocated to the training required for $R \& D$ personnel $(\%)=($ Budget allocated to the education/Total R\&D budget). According to the responses obtained from the companies interviewed, these two ratios have an effect on the innovation ability of companies at approximately equal levels. Technical textile companies allocate $2.46 \%$ of their general budgets to $R \& D$ and $P \& D$ activities on average. According to the firms' responses, this ratio ranges between $0.5 \%$ and $15 \%$. The average R\&D expenditure ratio of the technical textile companies obtained is above the R\&D expenditure rate of Turkish GDP, which was 0.94 as of 2016 (30). Companies allocate $12,87 \%$ of their total R\&D budget to the training expenses of $\mathrm{R} \& \mathrm{D}$ personnel. It is observed that the rate of the budget allocated to education varies between $0.03 \%$ and $50 \%$. The last criteria that affects the innovation ability of technical textile companies is the effectiveness of the communication channels of the companies. In terms of the aspects of communication, innovation-oriented communication with customers takes place on the top amongst the communication channels.

Accomplishments of the sector will be able to make important contributions at both micro and macro levels. From this point of view, our companies need to gain a proactive structure, by directing the customers to their new offerings of latest innovations, rather than implementing the product and process improvements based only on the demands of customers. In this way, Turkish technical textile companies may become a pioneer in both domestic

\section{REFERENCES}

1. İTKİB Tekstil, Deri ve Halı Şubesi, 2015, "Teknik Tekstil Sektörüne İlişkin Güncel Bilgiler", http://www.hightex2016.com/rapor1.pdf (Erişim tarihi:27.10.2016)

2. Trademap Veritabanı, 2017. https://www.trademap.org (Erişim tarihi: 08.09.2017)

3. European Commission Database, 2018. "European Innovation Scoreboard", http://ec.europa.eu/growth/industry/innovation/factsfigures/scoreboards/, (Erişim tarihi:07.09.2018)

4. Hollanders H, Es-Sadki N, Kanerva M. 2016. "European Innovation Scoreboard-2016", European Commission, Belgium, 96p.

5. Türk Patent ve Marka Kurumu, "İstatistikler", http://www. turkpatent.gov.tr/TurkPatent/statistics/ (Erişim tarihi:11.09.2017)

6. OECD ve Eurostat, 2005. "Oslo Kılavuzu, Yenilik Verilerinin Toplanması ve Yorumlanması İçin İlkeler", (Çev: TÜBİTAK), 3. Baskı, OECD-Eurostat Ortak Yayını, 163s.

7. Masum MH, Fakir A. 2014. "Implication of Balanced Scorecard in the Textile Sectors of Bangladesh: A Synopsis", Proceedings of The Fourth International Congress on Interdisciplinary Research and Development, 99.1

8. Karimov F. 2002. "Innovation and Efficiency: Application to Catalan Textile Industry", Universitat Autònoma de Barcelona, Departament d'Economia de l'Empresa, http://webs2002.uab.es/ edp/workshop/cd/Proceedings/3EDPW FKarimov.pdf, (Erișim tarihi: 18.09.2014)

9. Shouyu C, Wencong L. 2009. "The Key Factors Affecting Technological Innovation in Shaoxing' Textile Industry", Proceedings and foreign markets. Besides, the increase in innovation activities also stems from the increase in production and exports of the technical textile products. Similarly, the increase in production and exports is primarily due to the increase in consumption in the domestic market. Therefore, the compulsory usage of technical textiles in public places such as hospitals will provide significant advantages. In this regard, public procurement to be carried out in public areas such as medical and defense industries will enable domestic producers to move their existing facilities and productions to a more advanced level.

In addition to innovative applications, the regular implementation of innovation analysis inspections is also important in terms of sustainability of such applications. In order to be able to achieve this goal, information sources need to be constantly updated. In addition, the analysis of the data obtained because of the innovation analysis surveys together with additional economic indicators of the country, where the activities are carried out, will allow companies to analyze their innovation position in a healthier way. In addition, it has been observed that a database is needed for gaining detailed and concrete information about technical textile companies. This kind of a database that facilitates access to a range of information, such as the technical textiles branches of companies, product diversities etc., will be able to provide great advantages and communication opportunities for researchers, industrialists and retailers in both Turkey and abroad.

of the International Conference on Information Management, Innovation Management and Industrial Engineering, 137-140.

10. Pang JL, Lu YL, Han JY. 2009. 12-15 July "Application of multistage integrated fuzzy evaluation in technology innovation capability of textile industry", Proceedings of the Eighth International Conference on Machine Learning and Cybernetics, Baoding, 2504-2508.

11. Zhu J, Yan L, Wei G. 2011. "Evaluation on the Technological Innovation Ability of Textile Enterprise Based on the Structural Coordination", Proceeding of International Conference on Information Management, Innovation Management and Industrial Engineering, 440-443.

12. Kuştepeli Y, Gülcan Y, Akgüngör S. 2012. "The Innovativeness of the Turkish Textile Industry within Similar Knowledge Bases across Different Regional Innovation Systems", European Urban and Regional Studies 20(2), 227-242.

13. Ofluoğlu Küçük P. 2018. "Türk Teknik Tekstil Sektörünün İnovasyon Yeteneğinin Analizi", Ege Üniversitesi Fen Bilimleri Enstitüsü, Doktora Tezi, 183s. (Yayımlanmamış).

14. Saaty TL. 1990. "How to Make a Decision: The Analytic Hiearrchy Process", European Journal of Operational Research 48, 9-26.

15. Kuruüzüm A, Atsan N. 2001. "Analitik Hiyerarși Yöntemi ve İşletmecilik Alanındaki Uygulamaları", Akdeniz İ.I.B.F Dergisi 1, 83105.

16. Ömürbek N, Tunca Z. 2003. "Analitik Hiyerarşi Süreci ve Analitik Ağ Süreci Yöntemlerinde Grup Kararı Verilmesi Așamasına İlișkin Bir Örnek Uygulama", Süleyman Demirel Üniversitesi İktisadi ve İdari Bilimler Fakültesi Dergisi 18(3), 47-70. 
17. Riabacke M, Danielson M, Ekeberg L. 2012. "State-of-the-Art Prescriptive Criteria Weight Elicitation", Advances in Decision Sciences, 1-24.

18. Feng S, Xu LD. 1999. "Decision Support for Fuzzy Comprehensive Evaluation of Urban Development", Fuzzy Sets and Systems 105, 1 12.

19. Zuo R, Cheng Q, Agterberg FP. 2009. "Application of a Hybrid Method Combining Multilevel Fuzzy Comprehensive Evaluation with Asymmetric Fuzzy Relation Analysis to Mapping Prospectivity", Ore Geology Reviews 35, 101-108.

20. Minli Z, Wenpo Y. 2012. "Fuzzy Comprehensive Evaluation Method Applied in the Real Estate Investment Risks Research", Physics Procedia 24, 1815-1821.

21. Ofluoğlu P, Örk N, Mutlu M, Atılgan T. 2017. "The Best Supplier Selection by Using Analytic Hierarchy Process (AHP) and Fuzzy Comprehensive Evaluation (FCE) Methods: An Example of a Turkish Leather Apparel Company", Tekstil ve Konfeksiyon 27 (4), 326-333.

22. Guo L, Gao J, Yang J, Kang J. 2009. "Criticality Evaluation of Petrochemical Equipment based on Fuzzy Comprehensive Evaluation and a BP Neural Network", Journal of Loss Prevention in the Process Industries 22, 469-476.

23. Shen G, Lu Y, Wang M, Sun Y. 2005. "Status and Fuzzy Comprehensive Assessment of Combined Heavy Metal and OrganoChlorine Pesticide Pollution in the Taihu Lake Region of China", Journal of Environmental Management 76, 355-362.

24. Lihong M, Yaning C, Weihong L, Ruifeng Z. 2009. "Fuzzy Comprehensive Evaluation Model for Water Resources Carrying
Capacity in Tarim River Basin", Xinjiang, China, Chinese Geographical Science 19(1), 89-95.

25. Xie F, and Tang D. 2010. "The Application of AHP and Fuzzy Comprehensive Evaluation in Harmonious Level Measurement between Human and Water in City", Journal of Computational Information Systems 6(14), 4647-4655.

26. Yang L, Liu C, Zhang Z, Shi Y. 2009. "Control of Supply Risk based on Ranking Foreign Suppliers Using Pattern Search Weighted Fuzzy Comprehensive Evaluation", Proceedings of International Joint Conference on Computational Sciences and Optimization, 613-617.

27. Zhijie G, Jie J, Ping L. 2010. "Design and Application of Evaluation Model on Technical Innovation Ability of SMEs based on AHP and FCE", Proceedings of the 7th International Conference on Innovation \& Management, 494-498.

28. Yuan J. 2013. "Fuzzy Comprehensive Evaluation Enterprise Performance Management Model Based on AHP", International Journal of Digital Content Technology and its Applications (JDCTA), 7(6), 539-547.

29. Castellion G, Markham SK. 2013. "Perspective: New Product Failure Rates: Influence of Argumentum ad Populum and Self-interest", Journal of Product Innovation \& Management 30(5), 976-979.

30. TÜİK, "İstatistik Göstergeler Veritabanı", https://biruni.tuik.gov.tr/ gosterge $/$ ?locale $=\operatorname{tr}($ Erişim tarihi:04.01.2017) 